\title{
INFORMATION SUPPORT OF OVERLAND TRANSIT FREIGHT TRAFFIC THROUGH THE TERRITORY OF KAZAKHSTAN
}

DOI: $10.36724 / 2072-8735-2020-\mid 4-8-53-59$

Daulet Sh. Akhmedov,

AALR "Institute of space technique and technology",

Almaty, Kazakhstan, lacp@mail.ru

Denis I. Yeryomin,

AALR "Institute of space technique and technology",

Almaty, Kazakhstan, denis.e@bk.ru

Manuscript received 12 May 2020;

Revised 22 June 2020;

Dinara G. Zhaxygulova,

AALR "Institute of space technique and technology", Accepted 03 August 2020

Almaty, Kazakhstan, zhaxygulova.d@istt.kz

Rimma A. Kaliyeva,

AALR "Institute of space technique and technology",

Almaty, Kazakhstan, keshrim95@gmail.com

Keywords: transit, electronic seal, cargo transportation, information technology, transport corridor, satellite communications, navigation system

This article is devoted to the topic of transit land freight traffic through the territory of Kazakhstan. The paper considers international railway and road communication routes passing through the territory of Kazakhstan and connecting the countries of the European Union, Russia, Central Asian countries and China, as well as transport projects in which Kazakhstan plays the role of a land bridge between Asia, Europe and the Middle East. Statistical data on the volume of transit cargo transportation through the territory of Kazakhstan for the past $\mathbf{5}$ years is given. The issue of providing information support for transit freight traffic is considered as one of the elements contributing to the full use of the transit potential of the country. For realization of information support of transit land freight traffic in the work it is offered a hardware and software complex for managing international transport transit corridors, which consists of electronic seals, data centre (DC) and information portal, and functions with application of modern technologies of satellite navigation and communication. This hardware and software complex allows monitoring the movement of transit cargo and guarantees its safety by locking the doors of the cargo compartment of vehicles and containers with electronic seals, which besides the role of a locking and sealing device acts as a device for registration and transfer of data on the state of the monitored object to the DC. The data received in the DC are checked for integrity, analysed, archived and transferred to the information portal, which provides user access to the system for visualization.

Information about authors:

Daulet Sh. Akhmedov, Doctor of Technical sciences, Director, AALR "Institute of space technique and technology", Almaty, Kazakhstan

Denis I. Yeryomin, Master of Economics sciences, Deputy Development Director, AALR "Institute of space technique and technology", Almaty,

Kazakhstan

Dinara G. Zhaxygulova, PhD student, research fellow, AALR "Institute of space technique and technology", Almaty, Kazakhstan

Rimma A. Kaliyeva, Master of Engineering sciences, junior research fellow, AALR "Institute of space technique and technology", Almaty, Kazakhstan

Для цитирования:

Ахмедов Д.Ш., Еремин Д.И., Жаксыгулова Д.Г., Калиева Р.А. Информационное обеспечение сухопутных транзитных грузовых перевозок через территорию Казахстана // Т-Сотm: Телекоммуникации и транспорт. 2020. Том I4. №8. С. 53-59.

For citation:

Akhmedov D.Sh., Yeryomin D.I., Zhaxygulova D.G., Kaliyeva R.A. (2020) Information support of overland transit freight traffic through the territory of Kazakhstan. T-Comm, vol. 14, no.8, Pp. 53-59. (in Russian) 


\section{Introduction}

Effective use of the country's transit potential is necessary, as it contributes to the development of the transport sector, which is one of the main sectors of the economy and reflects the level of economic development of the country [1]. The Central Asian (CA) countries, and especially Kazakhstan, despite being landlocked, have a high transit potential [2], as they are located between such economic giants as China and Europe, the turnover between which only increases every year [3, 4]. Land transportation through Kazakhstan in the direction of China-Europe is much cheaper than air transportation and much faster than the traditional sea transportation [5]. Thus, transportation of cargoes from China to Europe through the territory of the Republic of Kazakhstan (RK) takes 7-9 days, while movement along the Trans-Siberian Railway takes up to 12 days, and sea transportation through the Suez Canal takes up to 35 days [6]. Besides, stable political situation in the country and absence of terrorism are additional advantages of Kazakhstan as a transit country.

Kazakhstan actively participates in international transport and communications programs and projects, for example, TRACECA (Transport Corridor Europe-Caucasus-Asia), North-South, Western Europe-Western China, etc., in order to attract transit traffic. Being a part of international transport and communication flows, Kazakhstan has such advantages as access to large seaports, acceleration and cost reduction for delivery of Kazakhstani goods to the world markets, increase in volumes of foreign and mutual trade with the countries-participants of corresponding projects and programs, modernization of economy and infrastructure of Kazakhstan that eventually contributes to the country's exit from the trap of transport isolation.

At the same time, transit potential of Kazakhstan is still not fully realized, thus requiring the taking of actions to improve the quality of services and, as a result, the efficiency of transit freight traffic through the country. To solve this problem, it is necessary to create conditions contributing to the increase in the capacity of transit routes, for example, improvement of the railway network [7] and road infrastructure [8], simplification of customs procedures for transit traffic [9], reduction of administrative barriers and elaboration of legal aspects of transit traffic [10], introduction of information technologies in the sphere of transportation of transit cargoes, etc.

In this case, the following goal is set in the present work: development of hardware and software complex for managing international transport transit corridors passing through the territory of the Republic of Kazakhstan, for information support of transit freight traffic.

\section{Land transport network of Kazakhstan}

Transit traffic through Kazakhstan is carried out along five railway [11] and six road [8] transcontinental transit corridors that connect the countries of Europe and Asia along routes whose Kazakhstani sections are shown in Figure 1.

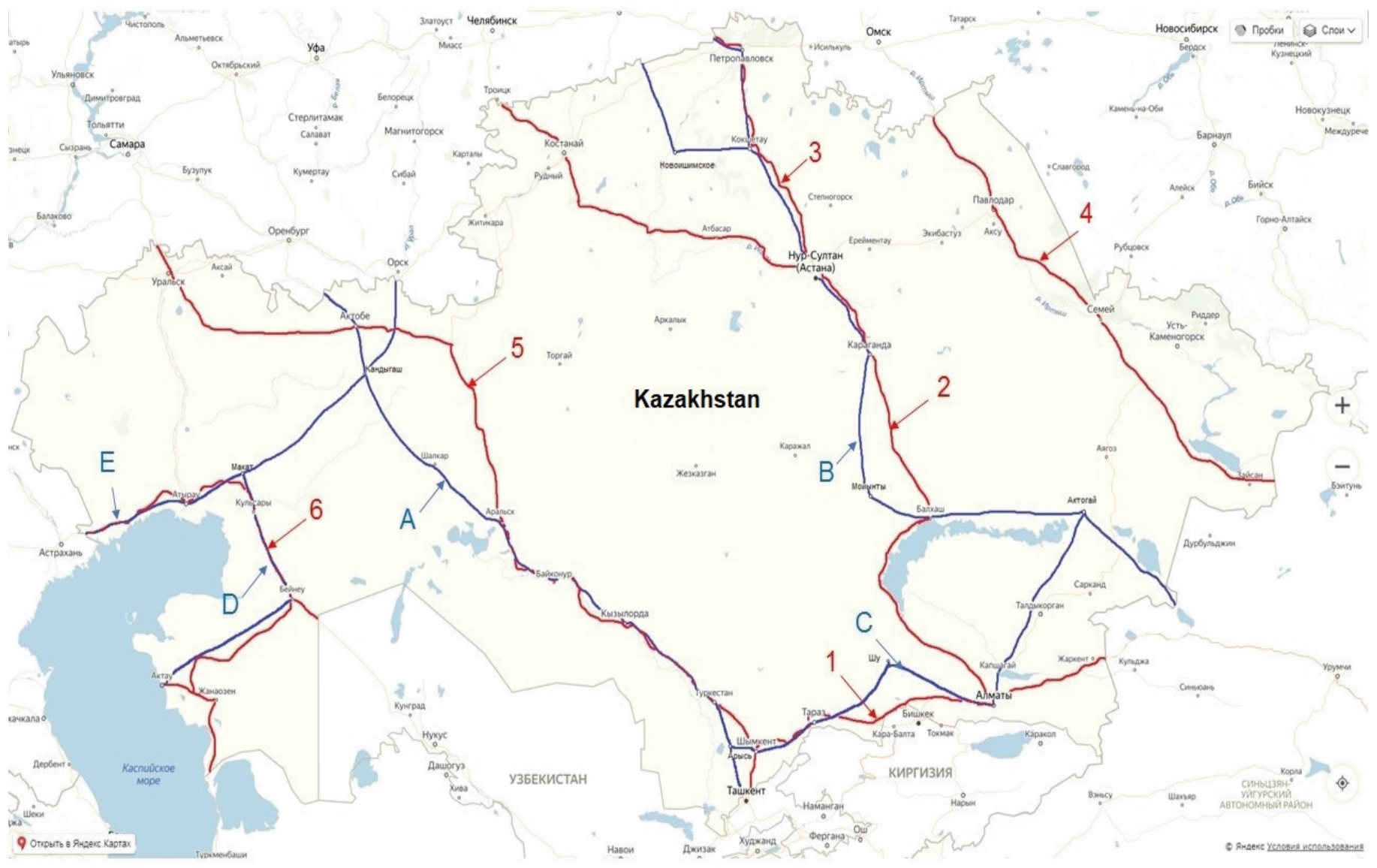

Figure 1. Automobile (marked in red, numbered) and railway (marked in blue, indicated by letters) routes passing through the territory of Kazakhstan and being part of international transport transit corridors 


\section{Railway corridors}

International railway transit corridors passing through Kazakhstan, shown in Figure 1, are exploited and developed under the TRACECA programme and the North-South and TransAsian Railway (TAR) projects.

The TRACECA Programme, initiated in 1993, is aimed at the development of the Europe-Caucasus-Asia transport corridor and is implemented with the participation of 13 countries [12]. The length of the route is $3836 \mathrm{~km}$. Within the TRACECA programme freight traffic by all types of transport is considered, but for the TRACECA member countries one of the key components of the transport system is railways [13]. Within the territory of Kazakhstan, the TRACECA transport corridor is realized by railways $\mathrm{A}, \mathrm{C}, \mathrm{D}, \mathrm{E}$.

The international transport corridor "North-South" with the total length of $7200 \mathrm{~km}$ connects the Baltic countries with India and the Persian Gulf countries along the Trans-Caspian, Eastern and Western routes [14]. The eastern land branch of the "NorthSouth" corridor runs through Kazakhstan by railways D and E.

TAR, which has a length of $114000 \mathrm{~km}$ and passes through 28 countries, is part of the concept of Pan-Asian transport communication, which was revived in 1992 by the Economic and Social Commission for Asia and the Pacific within the framework of the project of land transport infrastructure development in Asia [15]. TAR connects the Pan-Asian and Pan-European railway networks in various points, connecting the major ports of Asia and Europe, thus providing landlocked countries with better access to seaports. The northern corridor of TAR (railway B), the southern corridor of TAR (railway C) and the central corridor of TAR (railway A) pass through Kazakhstan.

In addition, in the field of rail transport, Kazakhstan participates in the "One Belt - One Route" initiative of China, including the "Economic Belt of the Silk Road" and the "XXI Century Silk Road", which was launched in late 2013 by the President of the People's Republic of China Xi Jinping as a new model of international cooperation to unite the transport and logistics network and strengthen economic cooperation in the region $[16,17]$. The One Belt - One Route initiative considers the sea route and six rail routes as the main freight flows, two of which run through Kazakhstan by railways $\mathrm{A}$ and $\mathrm{C}$.

In this regard, the initiative "One belt - one way" in the territory of Kazakhstan is carried out in conjunction with the state program of infrastructure development "Nurly Zhol", one of the objectives of which for 2020-2025 is to promote the involvement of "Greater transit" and the implementation of export policy through the development of effective transit, export and logistics infrastructure [18].

\section{Automobile corridors}

Road transit transport corridors passing through Kazakhstan, as shown in Figure 1, are part of the European [19] and Asian [15] transport networks (Table 1). For example, road 1 is part of the longest European route E40, about $8000 \mathrm{~km}$ long, starting in France and ending in Kazakhstan, and the Asian Highway AH5, $10380 \mathrm{~km}$ long, starting from Shanghai and ending in Istanbul. In addition, road 1, along with road 2, is the Kazakhstan part of the Western China-Western Europe route described in more detail below. At the same time, the most intensively used transport corridors, according to the work [8], are roads number 1, 2, 3 connecting China with the CA countries and Russia.
Table 1

Kazakhstan's roads in European and Asian transport networks

\begin{tabular}{|c|c|c|c|c|}
\hline $\begin{array}{c}\text { Road } \\
\text { Sign in } \\
\text { Fig.1 }\end{array}$ & Road & $\begin{array}{c}\text { Euro } \\
\text { route }\end{array}$ & $\begin{array}{c}\text { Asian } \\
\text { Highway }\end{array}$ & $\begin{array}{c}\text { Road length on } \\
\text { the territory of the } \\
\text { RK, km }\end{array}$ \\
\hline 1 & A2 (M39) & E40 & AH5 & 1197 \\
\hline 2 & M36 & $\begin{array}{c}\text { E125, } \\
\text { E016, E123 }\end{array}$ & $\begin{array}{c}\text { AH60, } \\
\text { AH7 }\end{array}$ & 2047 \\
\hline 3 & A1 & E125 & AH64 & 452 \\
\hline 4 & M38 & E127 & AH60 & 1081 \\
\hline 5 & M32 & E38 & AH61 & 2060 \\
\hline 6 & A27, A33 & E40, E121 & AH70 & 1416 \\
\hline
\end{tabular}

The road infrastructure of Kazakhstan has been greatly developed as a result of the "Western China - Western Europe" project, which aims to provide cargo transportation in three main directions: China - Kazakhstan, China - CA, China - Kazakhstan - Russia - Western Europe. The "Western Europe - Western China" transport corridor runs along the route St. Petersburg - Mos ow - Nizhny Novgorod - Kazan - Orenburg - Aktobe Kyzylorda - Shymkent - Taraz - Kordai - Almaty - Khorgos Urumqi - Lanzhou - Zhengzhou - Lianyungan and has a length of $8445 \mathrm{~km}$. At the same time, $2233 \mathrm{~km}$ of the corridor passes through the territory of Russia, $2787 \mathrm{~km}$ - through Kazakhstan, $3425 \mathrm{~km}$ - through China [20].

Within the "Western China - Western Europe" project, 2452 $\mathrm{km}$ of roads were reconstructed in Kazakhstan: $1,390 \mathrm{~km}$ of $1 \mathrm{st}$ technical category roads with 4 lane traffic (KyzylordaTurkestan-Shymkent-Taraz-Almaty-Korgos), 1,062 km of 2nd technical category roads (border of Russia-Martuk-AktobeKarabutak-Kyzylorda); geometrical parameters of the route (turns, visibility, slopes) are improved, bypassing of settlements (Aktobe, Shagan, Aralsk, Kyzylorda, Shieli, Zhanakorgan, Turkestan, Ikan, Temirlan, Shymkent, Taraz, Kulan, Tashkarasu, Zharkent, Kordai, Mashat, Kuyuk passes) is made to reduce environmental impact [21].

\section{Statistical data on transit traffic through the territory of Kazakhstan}

According to the data of the Ministry of Industry and Infrastructure Development of the Republic of Kazakhstan [22, 23] and JSC "National Company "Kazakhstan temir zholy" [24, 25] the volume of goods transported through the territory of Kazakhstan shows positive dynamics over the last five years (Figure 2). At the same time, the majority of cargo is transported by rail, which is explained by the fact that this type of transport is used to transport oil, ferrous metals, products of chemical industry and grain. Road transport is used for transportation of electronic equipment, plant products, consumer goods, textiles and their products.

In particular, in 2019, 19.47 million tons of transit cargoes were transported by land through the territory of Kazakhstan to the European Union (EU), CA, Russia and China in the volumes presented in Table 2 [23]. As can be seen, at present the main direction of freight transit traffic through Kazakhstan is the CA countries. At the same time, the EU countries represent a promising direction, increasing cargo turnover through which contributes to the connection of such economic giants as China and EU 
countries, which, in turn, contributes to the strengthening of political influence and economic position of Kazakhstan in the international arena.

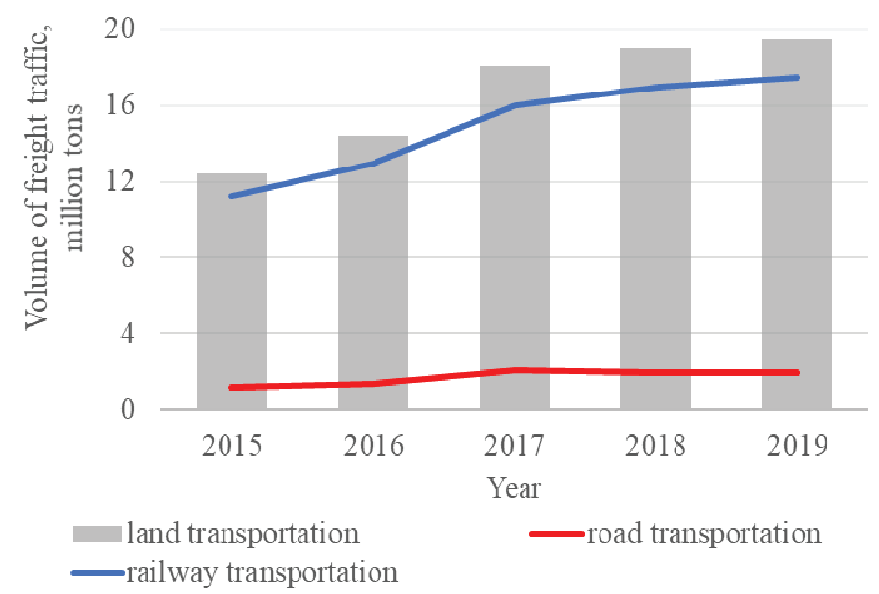

Figure 2. Dynamics of transit cargo transportation through the territory of Kazakhstan for the period of 2015-2019

Table 2

Quantitative data on the volume of transit cargo transportation through the territory of Kazakhstan

\begin{tabular}{|c|c|c|c|c|}
\hline \multirow{2}{*}{ Destination } & \multicolumn{2}{|c|}{$\begin{array}{c}\text { Volume of freight traffic, million } \\
\text { tons }\end{array}$} & \multicolumn{2}{c|}{ Total } \\
\cline { 2 - 5 } & by railway & by road & $\begin{array}{c}\text { million } \\
\text { tons }\end{array}$ & $\%$ \\
\hline CA & 13. & 1.36 & 14.71 & 75.5 \\
\hline China & & 0.03 & 2.44 & 12.6 \\
\hline EU & 1. & 0.12 & 1.36 & 7.0 \\
\hline Russia & & 0.46 & 0.96 & 4.9 \\
\hline Total & & 1.97 & 19.47 & 100 \\
\hline
\end{tabular}

In 2019, Kazakhstan earned over KZT 450bn from transit transport, but it is assumed that real income may be higher if various schemes of "hidden" cargo transit by rail and road are excluded.

\section{The system for managing international transport transit corridors}

The System for Managing International Transit Transport Corridors (hereinafter referred to as the System) is a hardware and software complex for managing international transport transit corridors developed on the basis of modern information and communication technologies. The System performs functions of monitoring of vehicles movement and determination of cargo location, assessment of conformity of the actual route of movement with the planned route, control of cargo safety and compliance with the transit cargo transportation regime.

The System has a geographically dispersed structure with many remote sources of input data in the form of electronic seals, remote user access to the System through an information portal and centralized data centre management. Electronic seals are an on-board navigation terminal with a mechanical locking device. Electronic seals are installed on the doors of the cargo compartment of the vehicle or wagon, they lock and control the closed state of the doors during the route. Electronic seals provide measurement of object location coordinates by signals of GLONASS/GPS global navigation satellite systems, measurement and automated data collection from condition monitoring sensors and data transmission to the DC via GSM and Iridium mobile cellular communication channels (in case of unavailability of cellular communication). The DC ensures continuous and parallel in time reception of data from electronic seals on the state of observation objects, archiving and processing of the received data, deletion of outdated data from the archive and transfer of data to the information portal. The information portal is a subsystem of dispatching control, display of System data and information delivery to users. The Information portal provides registration, register maintenance, access control and delimitation of powers of system users, control of sufficiency of quantity of electronic seals in points of installation and removal, registration and removal from registration of electronic seals. The information portal provides a visual display of current and historical data on the condition of the objects under surveillance, a current location scheme and routes of movement of objects on the map, diagrams of the electronic seals sensor readings, and the possibility of exporting the report.

Thus, as a result of the System implementation, the following tasks can be solved:

- reduction of time and cost of cargo delivery due to control of optimal routes and compliance with the traffic schedule;

- providing information to users about the location and safety of goods;

- ontrol of transit goods movement;

- detection of violations of the goods transportation regime;

- interrupting the transportation of smuggled goods (ensuring product transparency in the market);

- reducing logistics costs through automation of processes;

- ontrol the payment of taxes and fees to the budget of the country;

$-r$ duction of the number of thefts and material damage from theft (electronic security control) through the rapid detection of the facts of opening or unlocking the cargo compartment.

\section{Conclusion}

The increasing trade turnover between China and European countries is raising interest in transcontinental land transportation, including through the territory of Kazakhstan. This paper shows the importance of railway and road transport corridors of Kazakhstan as elements of international transit corridors in projects for the transit transportation of goods in the direction of Asia-Europe. Statistical data show the growth of transit cargo turnover in the country over the past 5 years from 12 million tons to 20 million tons, with the main destination of transit cargoes transported through Kazakhstan, are the countries of Central Asia (in 2019, 75.5\% of the total volume of land transit cargo).

Along with the taken actions to increase the efficiency of use of Kazakhstan's transit potential through the development of railway and road infrastructure, it is proposed to introduce the 
system for managing international transport transit corridors. The functioning of the system for managing international transport transit corridors is based on the continuous monitoring of vehicle movements using satellite navigation and mobile communications, as well as the use of sensors for monitoring the closed state of the doors of cargo compartments of vehicles and containers. The implementation of the proposed system will provide information support for the transportation of goods to increase the confidence of foreign freight operators by land through Kazakhstan by providing consumers with the ability to track goods and vehicles, as well as to guarantee the safety of goods and prevent the illegal transportation of goods.

\section{References}

1. Ulezlova L.V. (2017). 'Struktura, tendencii i faktory razvitiya rynka otrasli telekommunikacij i svyazi', Problemy sovremennoj nauki i obrazovaniya, 13 (95), pp. 76-79.

2. Garbuzarova Y.G. (2019). 'Transportation and Communication Potential of Central Asia in the Focus of Global Actors Interests', Vestnik TGUPBP, 2 (79), pp. 137-147.

3. China [online]. Available at: https://ec.europa.eu/trade/policy/countries-and-regions/countries/china/ (Accessed: 02 March 2020).

4. Denisenko K. (2019). 'Kitajskij put' v Evropu', Ekspert, 22 (1121), pp. 17

5. Shaltykov A.I. (2015). 'Prospects of the transport hub in Kazakhstan', KNPU Bulletin, a series of "International Affairs and Politics", 4(43), pp. 21-29.

6. Akhmedov D.Sh., Yeryomin D.I., Zhaxygulova D.G., Trepashko S. (2019). 'Architecture of Transport Traceability System of Goods in the Republic of Kazakhstan', Herald of KBTU, 3 (16), pp. 335-342.

7. United Nations Economic Commission for Europe. (2019). Logistics and Transport Competitiveness in Kazakhstan. Geneva: UNITED NATIONS.

8. Bekmagambetov M.M., Kochetkov A.V. (2013). 'The Development of Road Transport Corridors of the Republic of Kazakhstan: Some Aspects of the Cross-Border Communications' Infrastructure Enhancement', Electronic Scientific Edition Almanac Space and Time, 1.

9. Devertsov S.I. (2017). 'The Concept of Customs Transit, its Types and Procedure', Sinergiya Nauk, 18, pp. 482-488.

10. Kusainova A.K., Nazarkulova L.T. (2018). 'Legal Regulation of Transport-Transit relations in Kazakhstan', Bulletin of Institute of Legislation and Legal Information of the Republic of Kazakhstan, 4 (53), pp. 77-84.

11. Classification of transport corridors [online]. Available at: http://www.portal.kazlogistics.kz/cn/zd/transport_corridors/ (Accessed: 09 March 2020).
12.

TRACECA - main page [online]. Available at: http://www.traceca-org.org/ru/glavnaja/ (Accessed: 09 March 2020).

13. Logistical processes and sea routes II in Armenia, Azerbaijan, Georgia, Kazakhstan, Kyrgyzstan, Moldova, Tajikistan, Turkmenistan, Ukraine, Uzbekistan. Master plan "LOGMOS", 2014.

14. Viskova A.Yu. (2019). International Transport Corridor "North-South", Molodoj issledovatel' Dona, 3 (18), pp. 19-23.

15. Bhattacharyay B.N. (2011). Toward a Sustainable Transport Development in Asia and the Pacific. CESifo Working Paper Series 3539. Munich: CESifo Group.

16. Abduramanova D.R. (2019). ' "Odin poyas, odin put'»: kratkaya harakteristika i vnutrennie celi Kitaya', Molodoj uchenyj, 29 (267), pp. 76-77.

17. Li N. (2018). "“One belt, one road" initiative as a new cooperation model of the PRC with Russia and Central Asia countries', RUDN Journal of World History, 4 (10), pp. 382-392. DOI: 10.22363/2312-8127-2018-10-4-382-392.

18. Ob utverzhdenii Gosudarstvennoj programmy infrastrukturnogo razvitiya "Nłrly zhol" na 2020 - 2025 gody [online]. Available at: https://tengrinews.kz/zakon/pravitelstvo_respubliki_kazahstan_premer ministr_rk/hozyaystvennaya_deyatelnost/id-P1900001055/ (Accessed: 09 March 2020).

19. Woodburn A., Allen J., Browne M., Leonardi J. (2008). 'The Impacts of Globalisation on International Road and Rail Freight Transport activity', Proceedings of the Global Forum on Transport and Environment in a Globalising World, Guadalajara, Mexico, November, 10-12 2008, $44 \mathrm{p}$.

20. Regional'noe sotrudnichestvo [online]. Available at: http://www.silk-road.kz/sites/default/files/infogr.jpg (Accessed: 16 March 2020).

21. $O$ hode stroitel'nyh rabot [online]. Available at: https://www.europe-china.kz/construction-work-progress (Accesseed: 16 March 2020).

22. Al'mukhamedova N. Transportnyj potencial Kazahstana: hochesh' stat' bogatym — postroj dorogi [online]. Available at: http://www.gov.kz/memleket/entities/transport/press/news/details/v2019-godu-cherez-kazahstan-perevezeno-194-mln-tonn-tranzitnyhgruzov?lang=ru (Accessed: 26 March 2020).

23. V 2019 godu cherez Kazahstan perevezeno 19,4 mln. tonn tranzitnyh gruzov [online]. Available at: http://www.gov.kz/memleket/entities/transport/press/news/details/v2019-godu-cherez-kazahstan-perevezeno-194-mln-tonn-tranzitnyhgruzov?lang=ru (Accessed: 26 March 2020).

24. Godovye otchety [online]. Available at: https://ktzhgp.kz/ru/media/news/news_main_section_ru/12983/ (Accessed: 26 March 2020)

25. V 2018 godu v tranzitnom soobshchenii ob"em perevozok gruzov sostavil $17 \mathrm{mln}$ tonn [online]. Available at: https://ktzhgp.kz/ru/media/news/news_main_section_ru/12983/ (Accessed: 26 March 2020). 


\section{ИНФОРМАЦИОННОЕ ОБЕСПЕЧЕНИЕ СУХОПУТНЫХ ТРАНЗИТНЫХ ГРУЗОВЫХ ПЕРЕВОЗОК ЧЕРЕЗ ТЕРРИТОРИЮ КАЗАХСТАНА}

Ахмедов Даулет Шафигуллович, ДТОО "Институт космической техники и технологий", АО "НЦКИТ", 2. Алматы, Казахстан, Іаср@mail.ru

Еремин Денис Иванович, ДТОО "Институт космической техники и технологий", АО "НЦКИТ", г. Алматы, Казахстан, denis.e@bk.ru

Жаксыгулова Динара Галимжановна, ДТОО "Институт космической техники и технологий", АО "НЦКИТ", 2. Алматы, Казахстан, zhaxygulova.d@istt.kz

Калиева Римма Абдыжапаровна, ДТОО "Институт космической техники и технологий", АО "НЦКИТ", г. Алматы, Казахстан, keshrim95@gmail.com

\section{Аннотация}

Статья посвящена теме транзитных грузовых перевозок сухопутным транспортом через территорию Казахстана. Рассмотрены международные железнодорожные и автодорожные пути сообщения, проходящие по территории Казахстана и связывающие страны Европейского союза, Россию, страны Центральной Азии и Китай, а также транспортные проекты, в которых Казахстан играет роль сухопутного моста между Азией, Европой и Ближним Востоком. Приведены статистические данные об объеме транзитных грузоперевозок через территорию Казахстана за прошедшие пять лет. Рассматривается вопрос обеспечения информационной поддержки транзитных грузовых перевозок как один из элементов, способствующих полноценному использованию транзитного потенциала страны. Для реализации информационной поддержки транзитных грузовых сухопутных перевозок в работе предлагается применение современного аппаратно-программного комплекса управления международными транспортными транзитными коридорами, который состоит из электронных пломб, центра обработки данных (ЦОД) и информационного портала, и функционирует с применением современных технологий спутниковой навигации и связи. Данный аппаратно-программный комплекс позволяет проводить мониторинг перемещения транзитных грузов и гарантирует их сохранность за счет запирания дверей грузового отсека транспортных средств и контейнеров электронными пломбами, которые наряду с ролью запорно-пломбировочного устройства выполняют функции устройства регистрации и передачи данных о состоянии объекта наблюдения в ЦОД. Полученные в ЦОД данные проверяются на целостность, анализируются, архивируются и передаются в информационный портал, который обеспечивает доступ пользователей к системе, для визуализации.

Ключевые слова: транзит, электронная пломба, грузовая перевозка, информационные технологии, транспортный коридор, спутниковая связь, навигационная система.

\section{Литература}

І Улезлова Л.В. Структура, тенденции и факторы развития рынка отрасли телекоммуникаций и связи // Проблемы современной науки и образования. 2017. №13 (95). С. 76-79.

2. Гарбузарова Е.Г. Транспортно-коммуникационный потенциал Центральной Азии в фокусе интересов глобальных акторов // Вестник ТГУПБП. 2019. №2 (79). С. I37-I47.

3. China // European Commission URL: https://ec.europa.eu/trade/policy/countries-and-regions/countries/china/ (дата обращения: 02.03.2020).

4. Денисенко К. Китайский путь в Европу // Эксперт. 2019. № 22 (II2I). С. 17.

5. Шалтыков А.И. Перспективы транспортного хаба Казахстана // Вестник КазНПУ, Серия "Международная жизнь и политика". 20।5. №4(43). С. 2I-29.

6. Ахмедов Д.Ш., Еремин Д.И., Жаксыгулова Д.Г., Трепашко С. Архитектура системы транспортной прослеживаемости товаров в Республике Казахстан // Вестник КБТУ. 2019. №3 (16). С. 335-342.

7. Logistics and Transport Competitiveness in Kazakhstan. Geneva: UNITED NATIONS, 2019. I8I p.

8. Бекмагамбетов М.М., Кочетков А.В. Развитие автотранспортных коридоров Республики Казахстан: некоторые аспекты совершенствования инфраструктуры трансграничных коммуникаций // Электронное научное издание Альманах Пространство и Время. 2013. №l.

9. Деревцов С.И. Понятие таможенного транзита, его виды и процедура // Синергия Наук. 2017. № 18. С. $482-488$. 


\section{TRANSPORT}

ІО. Кусаинова А.К., Назаркулова Л.Т. Правовое регулирование транспортно-транзитных отношений в Казахстане // Вестник Института законодательства РК. 2018. №4 (53). С. 77-84.

II. Классификация транспортных коридоров (ОСЖД) // KAZLOGISTICS URL: http://www.portal.kazlogistics.kz/cn/zd/transport_corridors/ (дата обращения: 09.03.2020).

12. Главная страница // TRACECA URL: http://www.traceca-org.org/ru/glavnaja/ (дата обращения: 09.03.2020).

13. Логистические процессы и морские магистрали II в Азербайджане, Армении, Грузии, Казахстане, Кыргызстане, Молдове, Таджикистане, Туркменистане, Узбекистане, Украине. Мастер-план "LOGMOS", 20I4. 256 с.

14. Вискова А.Ю. Международный транспортный коридор "Север-Юг" // Молодой исследователь Дона. 2019. №3 (I8). С. 19-23.

15. Bhattacharyay B.N. Toward a Sustainable Transport Development in Asia and the Pacific. CESifo Working Paper Series 3539 , CESifo Group Munich, 201 I. 46 p.

16. Абдураманова Д.Р. "Один пояс, один путь": краткая характеристика и внутренние цели Китая // Молодой ученый. 2019. №29 (267). С. 76-77.

17. Li N. "One belt, one road" initiative as a new cooperation model of the PRC with Russia and Central Asia countries // RUDN Journal of World History. 2018. №4 (10). P. 382-392. DOI: I0.22363/23 I2-8I27-20।8-10-4-382-392.

18. О6 утверждении Государственной программы инфраструктурного развития "Н?рлы жол" на 2020 - 2025 годы // Законы Казахстана URL: https://tengrinews.kz/zakon/pravitelstvo_respubliki_kazahstan_premer_ministr_rk/hozyaystvennaya_deyatelnost/idPI90000I055/ (дата обращения: 09.03.2020).

19. Woodburn A., Allen J., Browne M., Leonardi J. The Impacts of Globalisation on International Road and Rail Freight Transport activity /I Global Forum on Transport and Environment in a Globalising World, 10-12 November 2008, Guadalajara, Mexico, 44 p.

20. Региональное сотрудничество // BNEWS KZ URL: http://www.silk-road.kz/sites/default/files/infogr.jpg (дата обращения: 16.03.2020).

21. О ходе строительных работ // Международный транзитный коридор Западная Европа - Западный Китай URL: https://www.europe-china.kz/construction-work-progress (дата обращения: 16.03.2020).

22. Альмухамедова Н. Транспортный потенциал Казахстана: хочешь стать богатым - построй дороги // InoZpress URL: http://www.gov.kz/memleket/entities/transport/press/news/details/v-2019-godu-cherez-kazahstan-perevezeno-I 94-mln-tonn-tranzitnyhgruzov?lang=ru (дата обращения: 26.03.2020).

23. В 2019 году через Казахстан перевезено 19,4 млн. тонн транзитных грузов // Комитет транспорта Министерства индустрии и инфраструктурного развития Республики Казахстан URL: http://www.gov.kz/memleket/entities/transport/press/news/details/v-20I9godu-cherez-kazahstan-perevezeno-I 94-mln-tonn-tranzitnyh-gruzov?lang=ru (дата обращения: 26.03.2020).

24. Годовые отчеты // АO "НК "Казахстан Темир Жолы" URL: https://ktzh-gp.kz/ru/media/news/news_main_section_ru/I2983/ (дата обращения: 26.03.2020)

25. В 2018 году в транзитном сообщении объем перевозок грузов составил 17 млн тонн // Акционерное Общество "КТЖГрузовые перевозки" URL: https://ktzh-gp.kz/ru/media/news/news_main_section_ru//2983/ (дата обращения: 26.03.2020).

\section{Информация об авторах:}

Ахмедов Даулет Шафигуллович, д.т.н., директор, ДТОО "Институт космической техники и технологий", АО "НЦКИТ", г. Алматы, Казахстан Еремин Денис Иванович, магистр, заместитель директора по развитию, ДТОО "Институт космической техники и технологий", АО "НЦКИТ", 2. Алматы, Казахстан

Жаксыгулова Динара Галимжановна, PhD-докторант, научный сотрудник, ДтОО "Институт космической техники и технологий", АО "НЦКИТ", г. Алматы, Казахстан

Калиева Римма Абдыжапаровна, магистр, младший научный сотрудник, ДТОО "Институт космической техники и технологий", АО "НЦКИТ",

г. Алматы, Казахстан 